\title{
The Relationship between Credit Risk Management and Profitability between Investment and Commercial Banks in Palestine
}

\author{
Mohammed Bayyoud $^{1} \&$ Nermeen Sayyad ${ }^{1}$ \\ ${ }^{1}$ Al-Quds University, Jerusalem, Palestine \\ Correspondence: Mohammed Bayyoud, Al-Quds University, Jerusalem, Palestine. Tel: 1-647-8000-073. E-mail: \\ Bayoud2@yahoo.com
}

Received: July 30, 2015

Accepted: September 8, 2015

Online Published: October 25, 2015

doi:10.5539/ijef.v7n11p163

URL: http://dx.doi.org/10.5539/ijef.v7n11p163

\begin{abstract}
Credit risk management is one of the vital aspects of the financial institutions regardless of their nature. For a more comprehensive analysis of Palestine banking sector, investment and commercial banks both were chosen for assessing the relationship between credit risk management and profitability. Explanatory design of study helped in assessing the casual effect relationship between the research variables. The regression model was used for gathering quantitative findings while structured interview from bank managers was selected for gathering qualitative data. The findings of the regression model in the current study confirmed that there is no consequence of credit risk on profitability of commercial and investment banks of Palestine. Additionally, it was also found that there is no difference between the Palestinian commercial and investment banks concerning the relationship.
\end{abstract}

Keywords: credit risk management, profitability, commercial banks performance, investment banks performance, Palestine

\section{Introduction}

Credit risk management has turned out as a vital issue in the current intensely complicated and competitive business environment. Undoubtedly, after recent financial crisis, it can be believed that banking sector at present are the largest financial institutions. Businesses and industries are heavily dependent upon the credit grants from these banks. The uncertain and volatile financial environment all across the globe has increased credit risk for the banking institutions, which is ultimately affecting the level of their profitability (Berríos, 2013). Past studies have confirmed that bank performance in terms of profitability is directly associated with its credit risk. Favorable credit risk management leads to positive profits and vice versa. However, the extent of this relationship is strongly dependent upon the types of banking institution. Commercial banks, due to the nature of their business are exposed towards the high risk of non-payment from their borrowers. Additionally, the largest credit risk of commercial banks is loan. Aduda and Gitonga, (2011, p. 935) state that, "Although that credit risk exists throughout the other activities of the bank both on and off the balance sheet. These other activities include acceptance, inter-bank transactions, trade financing, foreign exchange transactions, futures, swaps, options and guarantees" but the significance of loan cannot be undermined. On the other hand, credit risk is not the sole high risks concentrated within the investment banks due to their nature of investing as well as financing activities. Credit and market risks both are vital for maintaining the profitability of such banks. Therefore, there is a possibility that an investment bank is simultaneously a commercial bank too (Li \& Zou, 2014). Therefore, in assessing real picture of a specific country's credit risk management and its impacts upon the profitability, the findings need to focus collectively on both the commercial banks and investments banks.

Current political and economic unrest in Palestine, make it a viable research base for the current study. Commercial and investment financial institutions are facing high credit risk and default incidences. This is the key reason why Palestinian banks remain cautious in selecting practices for credit risk management, borrowers and investors (Alkhatib, 2012; Berríos, 2013). (Alkhatib, 2012; Berríos, 2013). There is range of local studies available assessing the financial performance of Palestinian commercial banks in context of credit risk management, however these past studies have lacked concerns on the association between credit risk management and profitability in commercial banks and investment banks in Palestine. Alkhatib, (2012, p. 175) in his research has endeavored to measure the overall fiscal presentation of commercial banks within Palestine. The study consider the relationship between the credit risk on the Internal-based performance Internal-based 
performance measured by Return on Assets, Market-based performance measured by Tobin's $Q$ model (Price I Book value of Equity) and Economic-based performance measured by Economic Value add'. Likewise, in another research by Ali (2005), the author aims to investigate the practical measures of credit risk in Palestine commercial banks. The findings were vital in identifying the most significant variables that have an effect on risk level of credit commercial banks in Palestine. It can be examined that aforementioned studies only provide valuable insights about the credit risk management in the country but they fail to focus upon the clear association between the credit risk management and profitability in commercial banks and investment banks in Palestine. This gaps and fixtures in past studies give rise to the research question of the current study i.e. "up to what extent, credit risk management is related with the profitability in commercial banks and investment banks in Palestine?"

For responding to this research question, the current article tries to develop a connection between credit risk management and profitability by using ROE (return on equity) ratio. Aduda and Gitonga (2011) in their literature have substantiated the effectiveness of ROE indicator for assessing similar relationship for Kenyan commercial banks. The next section of the study presents a comprehensive theoretical framework for primary investigation in subsequent parts.

\section{Literature Reviews}

\subsection{Credit Risk}

Brown and Moles (2014) define credit risk as the risk related with the loans; banks lend to the borrower and normally charge a fee against it. The banks redistribute its finance in the form of debt to borrowers, which is needed to be paid back by the distributors. However, there is no assurance of the fact that such amount would be re-paid by the borrowers and the risk of default is always there for the banks on lend loans. Financial researchers and analysts regard such risk as credit risk.

According to Bank of Palestine, credit facilities in the Palestinian banks have risen significantly after the global crisis. The major contribution was placed between the years of 2008 and 2011, when the credit accelerates itself from the USD 1.72 billion dollars to USD 3.5 billion. The authorities associate the increased position of the sector with the improvements in the operations of the underserved Palestinian market and the improvement in the operations of Palestinian banks (Musmar \& Mraish, 2012). The published growth rates in the credit facilities of Palestinian commercial and investment banks can be examined from the below given figure.

\begin{tabular}{|c|c|c|c|c|c|}
\hline & 2008 & 2009 & 2010 & 2011 & CAGR \\
\hline Qatar & $51.1 \%$ & $11.5 \%$ & $16.4 \%$ & $28.3 \%$ & $13.6 \%$ \\
\hline Palestine & BASE & $25.7 \%$ & $30.9 \%$ & $23.3 \%$ & $19.7 \%$ \\
\hline$K S A$ & $25.2 \%$ & $-1.1 \%$ & $5.2 \%$ & $10.5 \%$ & $3.6 \%$ \\
\hline Jordan & $15.5 \%$ & $2.1 \%$ & $8.5 \%$ & $9.7 \%$ & $5.0 \%$ \\
\hline$U A E$ & $47.5 \%$ & $3.7 \%$ & $1.4 \%$ & $2.1 \%$ & $1.8 \%$ \\
\hline Kuwait & $35.0 \%$ & $13.2 \%$ & $3.9 \%$ & $0.5 \%$ & $4.3 \%$ \\
\hline
\end{tabular}

Figure 1. Growth rates of credit facilities in selected countries (Musmar \& Mraish, 2012)

\subsection{Credit Risk Management in Commercial Banks and Investment Banks}

According to Hosna, Manzura, and Juanjuan, (2009) credit risk is the most significant risk in the commercial banks due to its association with the possible losses. The author divided credit risk into three different types such as default risk, exposure risk and recovery risk. They also argue that commercial banks consider credit risk in relation to bank loans. Therefore, there credit risk management is dependent upon the overall analysis and investigation of the market. The banks have to take account of the different types of losses within their risk management process. These include expected losses (EL), unexpected losses (UL) and loss given default (LGD) (Hosna, Manzura, \& Juanjuan, 2009).

Aduda and Gitonga (2011) further stated that generally financial institutions adopt range of techniques for the mitigation of their credit risk. According to them, the commonly used techniques include collateral, guarantees, and net-off loans. These loans are netoff with the help of receipt, leading to decreased credit risk. In other studies, insurance, factoring, debt compilation, surety bonds, and letter of credit (LC) are recognized as extensively used methods of risk management (Aduda \& Gitonga, 2011). According to Vaidyanathan (2013) the reason behind development and implementation of range of credit risk techniques can be confirmed from the fact that better and improved system for credit risk management can lead to timely risk evaluation, appropriate organizational 
setup and effective system of credit monitoring.

However, it can be argued that due to the use of aforementioned techniques there is a possibility that credit risk is decreased while other type of risks increases including legal risk, operational risk, liquidity risk and market risk. Therefore, Hibbeln (2010) has emphasized upon the fact that in the management of credit risk, businesses must look at the risk in terms of opportunities as well as threats. Hanmanth and Shivaji (2014) argue that more risk results in more profitability therefore business managers in the financial institutions also believe that the credit risk cannot be eliminated from the business portfolio.

\subsection{Bank Performance Measures}

In past studies, the researchers for determining profitability use several measures. Some use qualitative performance aspects while other associate financial quantitative indicators with profitability. Brealey and Myers (2003) have stressed that there are diverse significant measures that could be used in investigating the profitability of a business institution. According to them, these include net profit ratio, ratio of return on assets (ROA), and ratio of return on equity (ROE). The authors discussed the procedure introduced by past researcher David Cole in 1972. Cole put forth the ratio analysis method for the evaluation and assessment of the banks' performance (Cole, 1972).

According to this process, an investigator of bank profitability must focus upon the source and size of the financial institution in relation to the amount of risk, it has accepted. Cole believed that income statement of a bank is the core and foremost source for driving the measures of performance for it. Therefore, he stated that there are several measures of profitability. One of such measure is the ratio of net income to equity i.e. the accounting return on equity (ROE). ROE can also be used for serving as a target measure for determining profitability at the overall level. Likewise, Cole also explained Market Return on Equity as an important profitability measure (Koch \& MacDonald, 2014). According to him, it is a price return, or the ratio of the price difference between two different points of time of the bank's shares. However, the use of different ratios is dependent upon the situations faced by the financial institution. One of such situation can be the point when the price earnings ratio stays steady and stable, it can provide a profitability yardstick. Therefore, it is worthy to note down that both ROE and the market return on equity should be considered after aligning it with what is expected by the banks' shareholders regarding the related risk level. The third ratio highlighted by Cole is Return on assets (ROA). However, difference between ROA and other discussed above is the fact that it is used to assess profitability of the banking transactions. The most widespread computation of ROA that could be examined in past studies is the ratio of the present and available periodical proceeds, interest proceeds and present bills, divided by asset balance (Cole, 1972). ROA could be categorized into four components parts in context of an accounting distinctiveness: Formula used by Aduda \& Gitonga, (2011) reveals following equation.

$$
\text { Profitability }=R O A=N I / T A+N I I / T A-O V / T A-L L P / T A
$$

Where, NI represents income on net interest amount, NII represents amount of non-interest income, OV refers to the non-interest overhead expenses and LLP defines loan loss provisioning (Ross, Westerfield, Jordan, \& Jaffe, 2007).

\subsection{Past Studies on Relationship between Credit Risk Management and Profitability}

Range of past studies has already provided sufficient evidences to confirm the relationship between the credit risk management and profitability. Gholami and Salimi (2014) conducted one of such research study in which authors have investigated the relationship between credit risk management and liquidity management and the profitability in banking sector. Authors stated that that based on the series of practical solutions, a significant relationship of credit risk management with profitability was evident. It was further stated that banks' financial statements are immensely affected by the credit risk. In other words, for increasing the business profitability, credit risk monitoring must be perfect. The study concluded a negative relationship between the credit risk and the profitability. In contrary, Afriyie and Akotey (2012) have presented a different association between these two research variables through a study on the credit risk management and profitability of selected rural banks in Ghana. According to authors, there is a noteworthy positive association between the non-performing loans and profitability levels of the banks performing in the rural areas. In other words, the banks with higher loans can still show profits. This is due to the inappropriate policies for credit risk management of the banks. The banks in Ghana shift their overall price on non-payment of loan to other customers in the form of elevated interest rate on loans.

Similarly, Gizaw, Kebede, and Selvaraj (2015) have focused on the relationship between credit risk management and profitability levels of the banks operating in Ethiopia on commercial basis. The findings of research revealed 
that there is a significant relationship between the non-performing loan, loan loss provisions and capital adequacy within the commercial banks of Ethiopia. Angeela (2010) has showed a no relationship between the non-performing loans and the profits figures for Kenyan banks within the financial statements. The low profits of the banks were found even within the period when the credit facilities of the banks were also very low. It was thus, confirmed by the authors that profits of commercial banks are not influenced as a result of the credit amount and nonperforming loans but other variables in the financial statements can be attributed to the low profits of the banks in Kenya. In contrary, Aduda and Gitonga (2011) by using the regression model found a reasonable level relationship between the credit risk management and the Kenyan banks profitability level.

Thus, the diverse set of results discussed in the literature by past authors spread across different geographical boundaries, the importance of the relationship between these two research variables become evident for the Palestinian financial institutions in the present research. The next section of research article presents an overview of the data and methodology chosen in the present research.

\section{Data and Methodology}

\subsection{Research Purpose, Sample Selection, Data Collection and Description of Dependent and Independent Variables}

In this paper, explanatory research design was used. The chosen design was appropriate in developing the cause and effect relationships between the two key research variables of the research i.e. credit risk management and profitability within the commercial and investment banks in Palestine. The purpose of current study was to assess the extent of relationship along with the detailed description of current situation in Palestinian banks. $\mathrm{McNabb}$ (2004) defines explanatory research a study used for the development of the causal explanation of some social phenomenon. The design was therefore helpful in using the theories for the predicting the future behaviors and circumstances in the Palestinian banks.

The current study undertakes the examination of all commercial and investment banks population in Palestine as at 31 December 2014. All the banks chosen were licensed and registered under the Banking Act. All these banks made the target population for the research. According to Babbie (2007), population represents the group of people sharing the similar characteristics and upon which the study results could be generalized. There is not large number of banks in Palestine (total 40 banks including national and foreign ones (Bank Swift IFSC Codes, 2015) including both commercial and investment banks) therefore the sample size was not too large. Half of them were national or local Palestinian banks. The random sample of 15 financial institutions was extracted from the local banks' population that made up of approximately $75 \%$ of the entire population. The good representation of sample offered a reliable base for the valid and reliable conclusions. Moreover, both primary and secondary data sources were used in this study. Primary data was collected using structured questionnaire sent to identify the relationship between profitability and credit risk management of banks. The researcher used e-mail methods for sending questionnaire to the banks managers in order to gather timely and cost-efficient information set from the respondents. On the other hand, for quantitative information data was extracted from the published financial statements of the banks for a period of 5 years i.e. 2010-2014. The data was obtained from the official database. ROE was used as the indicator of profitability in the regression analysis.

In using ROE as the indicator of profitability, it was also considered highly necessary to consider the information, which is easily available within the financial statements of the business organizations. In order to deal with this NPLR (Non-Performing Loan Ratio) was considered as independent variable. Additionally, Ara, Bakaeva, and Sun (2009), and Brewer and Jackson (2006) are some of the other authors, who have considered similar direction within their research studies. They define NPLR TLs (total loans) dividing NPLs. For the measurement of this ratio, the researcher utilized data offered in the financial statements each bank for a period of five years (i.e., from 2010 to 2014). The loan amount was presented in the balance sheet of the banks in their annual reports. The formula used for the calculation is given below:

$$
N P L R=(N P L \text { amount }) \div(\text { TL amount })
$$

\subsection{The Empirical Model}

The regression analysis as used in past studies,was recognized as important for seeking the relationship between credit risk management and profitability in commercial banks and investment banks in Palestine. For this purpose, the researcher used the following regression model presented below as used by Aduda \& Gitonga, (2011) in their research:

$$
Y=\alpha+\beta 1 X
$$

That is: 
(1) Standard: $Y$ - the value of dependent variable;

$\alpha$-The constant term;

$\beta$-The coefficient of the function;

$X$ - the value of independent variables.

(2) Application: $Y$-ROE-profitability indicator;

$N P L R$ — credit risk management indicator.

Thus, the regression equation becomes:

$$
R O E=\alpha+\beta N P L R
$$

The regression function describes the relationship between the research variables i.e. X (NPLR) to Y (ROE). It is worthy to note that $\alpha$ is the constant term $\beta$ is the coefficient of the function; it is price for the regression equation used for forecasting the variances in dependent variable from the independent variables (Aduda \& Gitonga, 2011). In the next section, results of research are presented with critical discussion.

\section{Results and Discussions}

The results of the structured questionnaire were received for 10 banks out of 15 sent. Most of the managers were male (8) at the high-level management position (7) with experience of more than 5 years (8). The education level of the manager was bachelors' degree (6 out of 10). It showed that Palestinian banks do not concentrate on the educational attainment and competencies of the management. The results of the structured survey revealed that out of 10, 3 banks use return on assets for measuring their profitability while five use return on equity. While the other two remaining banks focuses upon both the indicators for predicting the profitability level.

The results of table 1 confirms that average value of ROE for the Palestinian banks had a mean of 2.53 and a standard deviation of 1.42 while NPL for the banks had mean of 65.23 and std deviation of 24.88.

Table 1. Descriptive statistics showing variation in the sample of ROE and NPLR of Palestinian banks

\begin{tabular}{lccccc}
\hline \multicolumn{5}{c}{ Descriptive Statistics } \\
\hline ROE & $\mathrm{N}$ & Minimum & Maximum & Mean & Std. Deviation \\
NPLR & 15 & .00 & 5.60 & 2.5369 & 1.42270 \\
Valid N (list wise) & 15 & 25.60 & 102.15 & 65.3460 & 24.88746 \\
\hline
\end{tabular}

On the other hand, Table 2 depicting regression analysis results reveal that only 16.3 percent (adjusted R square $=.163$ ) likelihood is present for the Palestinian commercial and investment banks that the profitability of the banks would be affected by credit facilities. In the past five years, it can be analyzed that although the credit facilities of the Palestinian banks have increased but it has not placed any significant impact on the banks profitability.

Table 2. Linear regression model summary showing results for NPLR as predictor of ROE in Palestinian banks

\begin{tabular}{lllll}
\hline \multicolumn{4}{c}{ Model Summary } \\
\hline Model & $\mathrm{R}$ & $\mathrm{R}$ Square & Adjusted R Square & Std. Error of the Estimate \\
1 & $.472 \mathrm{a}$ & .223 & .163 & 1.30179 \\
\hline
\end{tabular}

a. Predictors: (Constant), VAR00002,

The results of empirical data also confirm that there is no relationship between the credit risk and profitability of the commercial and investment banks in the country. The reason behind it can be the improved and effective policies of credit risk management. The results of for Anova given in Table 3 and Table 4, with $\mathrm{F}=3.721$ and $\mathrm{p}$ value of 0.76 greater than alpha $=0.05$ rejects any type of significant association between the banks. The findings of the structured interviews also confirmed in determining the effect of practices for credit risk management on profits that there is no effect of credit facilities on banks profitability. The reason respondents gave in relation to such relationship showed that credit risk management principles were applicable in the banking institutions. 
Table 3. One-factor anova results showing significance in relationship between NPLR and ROE in Palestinian banks

\begin{tabular}{lcccccc}
\hline \multicolumn{7}{c}{ ANOVA $^{\mathbf{b}}$} \\
\hline Model & & Sum of Squares & df & Mean Square & F & Sig. \\
\hline 1 & Regression & 6.306 & 1 & 6.306 & 3.721 & $.076^{\text {a }}$ \\
& Residual & 22.031 & 13 & 1.695 & & \\
& Total & 28.337 & 14 & & & \\
\hline
\end{tabular}

a. Predictors: (Constant), NPLR;

b. Dependent Variable: ROE.

Table 4. Coefficients showing results for dependency between NPLR and ROE in Palestinian banks

\begin{tabular}{lcccccc}
\hline \multicolumn{7}{c}{ Coefficients $^{\mathbf{a}}$} \\
\hline & & \multicolumn{7}{c}{ Unstandardized Coefficients } & Standardized Coefficients & & \\
\cline { 3 - 6 } Model & B & Std. Error & Beta & t & Sig. \\
\hline 1 & (Constant) & .775 & .973 & & .796 & .440 \\
& NPLR & .027 & .014 & .472 & 1.929 & .076 \\
\hline
\end{tabular}

a. Dependent Variable: ROE.

However, it was also found that commercial banks have quite easy process of credit management as compared to the investment banks. The reason can be justified from the secondary data reviewed above. It showed that there is a difference in the nature of both types of banks. The extent of activities for investment banks is higher than the commercial banks ( $\mathrm{Li} \&$ Zou, 2014). On the other hand, the increased credit facilities in the financial institutions of Palestine as confirmed through the current study further substantiate with the Musmar and Mraish (2012) findings i.e. 19\% increase in credit facilities for commercial banks, which was higher than other regions and countries. It is also worthy to notice that all of the respondents (10) confirm the significance of credit ratios in effectively defining the effects. They also confirmed the significant role played by economic sectors and consumer finance sector and individual committees in the risk allocation and management of funds on continuous basis. Therefore, it can be confirmed that credit risk management policy define the profitability in the Palestinian banks up to insignificant extent.

\section{Conclusion}

The paper confirms that there is no relationship between credit risk and profitability in such way that profits of banks are affected due to credit facilities. The majority of the managers confirmed the wide use of credit risk management principles within their institutions for the development of value and evaluating uncertainties associated with the business. The use of collateral is made for setting the limits and ceilings for the amounts of credit facilities. Appropriate collaterals are obtained from the customers. Respondents also confirm that an individual committee works in their banks for controlling the credit issues. However, it is worthy to note down that effects of bank size, credit risk in relation to capital adequacy, assets monitoring and operational administrations also contribute vitally on the financial performance of banks in Palestine. Furthermore, various ratios are used by the banks for determining their profitability level. These include return on assets and return on equity as vital ones. Return on equity and NPLR however were found effectively used in most of the past studies. It can be summarized at the end that there is no difference in the investment and commercial banks in relation to the association between credit risk and profitability.

\section{Suggestions for Further Research}

In this study, only credit risk was taken into account for assessing the relationship with the profitability of the commercial and investment banks in Palestine. Other studies can be conducted in order to measure the differences between them and profitability of Palestinian banks. Other studies could be used for making comparison between the credit risk management facilities in Palestinian banks and in other western and eastern banks. Additionally, research studies can use other financial indicators for measuring profitability other than ROE. This will further help in substantiating the findings of present study. Moreover, sample size of future studies could include commercial and investment banks, which are foreign and operating in Palestine. This would be helpful in clarifying the overall picture in front of the audience. 


\section{References}

Aduda, J., \& Gitonga, J. (2011). The Relationship Between Credit Risk Management and Profitability Among the Commercial Banks in Kenya. Journal of Modern Accounting and Auditing, 7(9), 934-946.

Afriyie, H. O., \& Akotey, J. O. (2012). Credit risk management and profitability of selected rural banks in Ghana. Ghana: Catholic University College of Ghana .

Ali, S. (2005). Risk management, financing and investing in banks. Investment and Finance in Palestine between the prospects of development and contemporary challenges. May 8 to 9, 2005: The Strip University.

Alkhatib, A. (2012). Financial Performance of Palestinian Commercial Banks . International Journal of Business and Social Science, 3(3), 175-184.

Angeela, M. K. (2010). Credit risk management and profitability of Commercial banks in Kenya. Nairobi: University of Nairobi.

Ara, H., Bakaeva, M., \& Sun, J. J. (2009). Credit risk management and profitability of commercial banks in Sweden (University of Gothenburg). Retrieved July 27, 2015 from http://hdl.handle.net/2077/20857

Babbie, E. (2007). The Basics of Social Research. Belomont: Cengage Learning.

Bank Swift IFSC Codes. (2015). List of Banks having SWIFT/BIC Code Branches in PS-Palestinian Territory. Bank Swift IFSC Codes. Retrieved July 27, 2015, from http://www.bankswiftifsccodes.com/swift-code/country/bic-code-ps-palestinian-territory-asia.html

Berríos, M. R. (2013). The relationship between bank credit risk and profitability and liquidity. The International Journal of Business and Finance Research, 7(3), 105-118.

Brealey, R. A., \& Myers, S. C. (2003). Principles of corporate finance. McGraw Hill.

Brewer, E., \& Jackson, W. E. (2006). A note on the risk-adjusted price concentration relationship in banking. Journal of Banking and Finance, 30, 1041-1054. http://dx.doi.org/10.1016/j.jbankfin.2005.06.006

Brown, K., \& Moles, P. (2014). Credit Risk Managment. Edinburgh: Edinburgh Business School.

Cole, D. (1972). A Return on Equity Model for banks. The Bankers' Magazine.

Gholami, A., \& Salimi, Y. (2014). Investigate the relationship between credit risk management and liquidity management and the profitability in banking sector. Academic Journal of Research in Business \& Accounting, 2(3), 2311-2326.

Gizaw, M., Kebede, M., \& Selvaraj, S. (2015). The impact of credit risk on profitability performance of commercial banks in Ethiopia. Academic Journals, 9(2), 59-66.

Hanmanth., N. M., \& Shivaji, W. (2014). Risk management in banks.

Hibbeln, M. (2010). Risk Management in Credit Portfolios: Concentration Risk and Basel II. Springer Science \& Business Media. http://dx.doi.org/10.1007/978-3-7908-2607-4

Hosna, A., Manzura, B., \& Juanjuan, S. (2009). Credit Risk Management and Profitability in Commercial Banks in Sweden. Master of Science in Accounting.

Koch, T., \& MacDonald, S. (2014). Bank Management. Cengage Learning.

Li, F., \& Zou, Y. (2014). The Impact of Credit Risk Management on Profitability of Commercial Banks. Umeå School of Business and Economics.

McNabb, D. E. (2004). Research Methods for Political Science. New York: M.E. Sharpe.

Musmar, F., \& Mraish, H. (2012). Bank of Palestine. AWRAQ.

Ross, S. A., Westerfield, R. W., Jordan, B. D., \& Jaffe, J. (2007). Corporate finance: Core principles and applications. McGraw Hill.

Vaidyanathan, K. (2013). Credit Risk Management for Indian Banks. New Dehli: SAGE Publications India.

\section{Copyrights}

Copyright for this article is retained by the author(s), with first publication rights granted to the journal.

This is an open-access article distributed under the terms and conditions of the Creative Commons Attribution license (http://creativecommons.org/licenses/by/3.0/). 